Andrew A. Adams, Kiyoshi Murata, Yohko Orito and Pat Parslow:

\title{
Emerging Social Norms in the UK and Japan on Privacy and Revelation in SNS
}

\author{
Abstract: \\ Semi-structured interviews with university students in the UK and Japan, undertaken in 2009 and 2010, are \\ analysed with respect to the revealed attitudes to privacy, self-revelation and revelation by/of others on \\ SNS.
}

\section{Agenda}

Introduction

Privacy and Revelation: Theory and Practice $\quad 21$

Who Are You? And Who's Your Friend?

Friends Don't Embarrass Friends Online $\quad 23$

$\begin{array}{ll}\text { Conclusions } & 24\end{array}$

\section{Authors:}

Prof Andrew A. Adams

- Centre for Business Information Ethics, Meiji University, 1-1 Kanda Surugadai, Chiyoda-Ku, Tokyo-To 101-8301, Japan

- $\quad$ aaa@meiji.ac.jp www.a-cubed.info

- Relevant publications:

- Adams, A. A., Murata, K. and Orito, Y.: The Development of Japanese Data Protection. Policy and Internet 2(2) art. 5, pp. 95-126, 2010. www.psocommons.org/policyandinternet/vol2/iss2/art5

- Adams, A. A., Murata, K. and Orito, Y.: The Japanese Sense of Information Privacy. AI \& Society 24(4), pp. 327-341, 2009. opendepot.org/209

- Brown, I. and Adams, A. A.: The ethical challenges of ubiquitous healthcare. International Review of Information Ethics 8, pp. 53-60, 2007. www.i-r-i-e.net/inhalt/008/008 9.pdf

Prof Kiyoshi Murata

- Centre for Business Information Ethics, Meiji University, 1-1 Kanda Surugadai, Chiyoda-Ku, Tokyo-To 101-8301, Japan

- kmurata@kisc.meiji.ac.jp + 81332962165 www.kisc.meiji.ac.jp/ ethicj

- Relevant publications:

- Murata, K. and Orito, Y.: The Right to Forget/Be Forgotten. Proceedings of CEPE 2011, pp. 192201, 2011.

- Murata, K. and Orito, Y.: Japanese Risk Society: Trying to Create Complete Security and Safety Using Information and Communication Technology. Computers and Soc iety 40(3), pp. 38-49, 2010.

- Murata, K. and Orito, Y.: Rethinking the Concept of the Right to Information Pri vacy: A Japanese Perspective. Journal of Information, Communication and Ethics in Society 6(3), pp. 233245, 2008. 
Dr Yohko Orito

- Faculty of Law and Letters, Ehime University, 3 Bunkyo-cho, Matsuyama, Ehime 790-8577, Japan

- orito@ll.ehime-u.ac.jp

- Relevant publications:

- Orito, Y.: The Counter-Control Revolution: "Silent Control" of Individuals through Dataveillance Systems, Journal of Information, Communication and Ethics in Society 9(1), pp. 5-19,2010. http://dx.doi.org/10.1108/14779961111123197

Mr Pat Parslow

- School of Systems Engineering, University of Reading, Whiteknights, Reading RG6 6AY, UK

- p.parslow@reading.ac.uk brains.parslow.net

- Relevant publications:

- Williams, S. A. Fleming, S. Lundqvist, K. and Parslow, P.: Understanding your digital identity, Learning Exchange 1 (1), 2010. learn-

ingexchange.westminster.ac.uk/index.php/lej/article/viewFile/17/14 


\section{Introduction}

Various figures in the media and technology worlds have claimed that the younger generation have no sense of privacy, or at least that they have got over the fact that they have no privacy anyway and embraced transparent life. ${ }^{1}$ Others such as Livingstone, ${ }^{2}$ Marwick et al., ${ }^{3}$ Marwick and boyd ${ }^{4}$ dispute this, and point to a clear understanding of the trades that are being made by teenagers between general visibility (their 15 minutes of fame), connectability (amongst existing connections and occasionally to potential new electronic connections) and privacy. Much of the existing work in this area focusses on a single culture, most particularly the US, and focusses on groups where Facebook is almost the only social networking site in use. In order to provide elements of a broader picture, semi-structured interviews were carried out with students at the University of Reading in the UK and at Meiji and Ehime Universities in Japan, using suitably translated versions of the same questionnaire. ${ }^{5}$ The result of the interviews were reviewed for similarities and differences in attitudes between the two sets of students.

The goal of the work was to understand the basic approach to using social networking sites amongst university-age students in the UK and Japan, with particular reference to:

- the identity of the target group for inclusion in their list of contacts;

- their attitudes towards identity, pseudonymity or anonymity on these sites;

- their attitudes towards self-revelation within a contact group and more broadly;

- their attitudes towards revelation by others of their information;

- their attitudes towards revelation by them of information about others;

- their attitudes towards revelation by third parties of information about that third party;

- their attitudes towards revelation by third parties of information about other third parties.

Even among this small group of interviewees (five from the UK and four from Japan) both some common factors and variations emerged. The different default settings of the systems used by subjects, including Mixi (the dominant Japanese SNS according to Alexa Internet Inc: www.alexa.com/siteinfo/mixi.jp) and Bebo (a significant but not dominant player in the European market) as well as Facebook, were discussed with the interviewees. One subject who agreed to be interviewed in the UK was not registered with any social network site and in addition to the relevant remaining questions on attitudes to others' revelations online, their reasons for deliberately and positively refraining from joining such sites were investigated.

1 Livingstone, S. (2008). Taking risky opportunities in youthful content creation: teenagers' use of social networking sites for intimacy, privacy and self-expression. New Media and Society, 10(3):393-411.

eprints.Ise.ac.uk/27072/1/Taking_risky_opportunities_in_youthful_content_creation_(LSERO).pdf.(Newspaper articles referred to in Endnotes 5-7.)

2 ibid. (Main text.)

3 Marwick, A. E., Murgia Diaz, D., and Palfrey, J. (2010). Youth, Privacy and Reputation (Literature Review). Technical Report 5, Berkman Centre. ssrn.com/abstract $=1588163$.

4 Marwick, M. and boyd, d. (2011). Tweeting teens can handle public life. The Guardian. www.guardian.co.uk/commentisfree/2011/feb/15/tweeting-teens-twitter-public-privacy.

5 based on a questionnaire created by Trottier of Queens University in Canada for his PhD work 


\section{Privacy and Revelation: Theory and Practice}

The advent of the Internet and particularly so-called Web 2.0 has provided everyone who is online with a vast opportunity for destroying their own and other's reputations on a much broader scale than in the past. Even refraining oneself from being online may not be a hindrance to fame or infamy on the social web, as explained by Solove ${ }^{6}$ in the cases of the Korean girl labelled gae-ttong-nyue (dog shit girl) after allowing her dog to defecate in a train carriage and refusing to clear it up, and of the Star Wars kid, whose childish imitation of a lightsaber routine went viral on the video sharing sites, much to his chagrin.

As Marx ${ }^{7}$ explains there are complex interplays of law and social norms at work in disclosing information whereby some information is required to be kept private, other information is required to be public, and others are required to be submitted to certain bodies in certain circumstances. Into this mix SNS have allowed not only self-revelation but revelation by/of others. In some cases, this revelation may be mistaken, such as when a photo tag is misapplied and identifies the wrong user. Where the photo is of something embarrassing this can be significantly harmful as shown by the reported practices of a substantial number of US firms who use online searches, including of SNS, to filter out "unsuitable" candidates. ${ }^{8}$ The practice is so prevalent and potentially harmful that the German federal government has introduced regulations banning employers from considering information posted on purely social network sites when considering job applications (professional-oriented sites such as LinkedIn sensibly remain fair sources). ${ }^{9}$

Surveillance by SNS and blog is not limited to potential employers, but includes school or university authorities, current employers, insurance companies and the police:

- Three baseball players at Kosei Gakuin High School in Aomori Prefecture in Japan, whose baseball team took the second place in the 2011 Koshien High School Baseball Tournament1, each separately posted on their mobile blogs about their underage drinking at Japanese-style pubs. One of them also posted salacious details of his dates with a female student who acted as an assistant manager to the team. Someone reported these posts to official at both the high school and the prefecture's high school federation. As a consequence, the players were suspended from school. All the local events to celebrate the vice championship were cancelled due to the scandals. ${ }^{10} 11$

- A University of Minnesota student in the US was suspended after making comments on her Facebook account which were considered threatening by staff at her school, when brought to their attention. ${ }^{12}$ The case here is rather reminiscent of the more disturbing example of Jake Baker from 1994 who posted a violent rape-and-murder fantasy story to a usenet newsgroup using the name of

6 Solove, D. J. (2007). The Future of Reputation. Yale University Press, New Haven, CT.

7 Marx, G. T. (2011). Turtles, Firewalls, Scarlet Letters and Vacuum Cleaners: Rules about Personal Information. In Aspray, W. and Doty, P. (editors), Privacy in America: Interdisciplinary Perspectives. Scarecrow Press, Lanham, MD. Early draft available at web.mit.edu/gtmarx/www/turtlesandfirewalls.html.

8 Microsoft (2010). Data Privacy: Perceptions Study. download.microsoft.com/download/E/0/9/E094917B-049C-4B00-AE65E97F55585C08/DPD_\%200nline\%20Reputation\%20Research.pptx. A survey whose results were widely reported in the press but for which no better presentation of the results is extant.

9 Out-Law.com (2010). German law bans facebook research for hiring decisions. www.out-law.com/page-11336.

10 Wall Street Journal (2011). Booze of Summer: Scandal Hits Koshien Baseball. blogs.wsj.com/japanrealtime/2011/08/25/booze-ofsummer-scandal-hits-koshien-baseball/. JapanRealTime Blog.

11 Matsuzawa, Y. (2011). Kosei Gakuin: the fact that three baseball players drank was detected online and they were suspended from school. Mainichi Shimbun. 22nd August. mainichi.jp/select/today/archive/news/2011/08/22/20110823k0000m040055000c.html. In Japanese.

12 Wobbema, T. (2009). U student suspended after threatening remarks on Facebook. The Minnesota Daily. www.mndaily.com/2009/12/16/u-student-suspended-after-threatening-remarks-facebook 
a classmate at the University of Michigan ${ }^{13}$ showing that such issues pre-date social networking sites (Baker was prosecuted but cleared of any illegal act).

- CBC reported the case of a Canadian woman whose employer's insurance company stopped her disability benefits for depression after she posted holiday pictures of herself smiling on a beach. ${ }^{14}$

- There were claims that riots in the UK in the summer of 2011 , initially sparked by a fatal shooting by police in London which spread to other areas of the capital and into other cities, were being coordinated using electronic messaging services, including SNS messages. Devon and Cornwall police, amongst other forces, have been investigating reports of messages inciting disorder and there have been a number of arrests made and verbal warnings against repeating such behaviour given. ${ }^{15}$

\section{Who Are You? And Who's Your Friend?}

One of the differences between various SNS is the word used to describe the connections a user has. In addition the directionality of such connections is interesting to note. LiveJournal, one of the earliest SNS still running, uses the word friend to indicate connections, but unlike sites such as LinkedIn, Facebook and Mixi, LiveJournal allows a user to add any other user to their list of friends without an acceptance of that status by the new friend. The academic-oriented site academia.edu has followers instead of friends and is similarly unidirectional, whereas the general professional networking site LinkedIn uses the very neutral term connections and has only bidirectional connections. The Japanese site Mixi uses mai-mikushi as the name of the link to the page listing one's connections. In a standard Japanese linguistic approach, this is shortened to mai-miku by most users and used as the descriptive noun for the connections in their social circle by many Japanese, including the interviewees. This did not appear to indicate any difference in attitude to their UK counterparts towards those online connections.

The UK interviewees generally used their real name on their SNS accounts, although not necessarily as their main visible screen name. This was reversed for the Japanese users with none of them having their real name explicitly included on their accounts, and often other strongly deanonymising information such as university department and/or degree course also withheld. Indeed they regarded those who did so as acting dangerously. This may be part of the reason that Facebook, with its strong policy on visible real names, has had little success in Japan. The Japanese interviewees all felt that since their primary use of the system was to maintain contact with people with whom they already had strong real world relationships, that online pseudonymity provided some extra security with no downside. They used other contact forms to pass SNS identity information to potential connections.

The UK interviews subjects all indicated that they distinguished in their minds between real friends and Facebook "Friends", although few of the UK or Japanese interviewees had many connections on their primary SNS whom they did not know in real life. Indeed, only one of the Japanese subjects stated that they were open to connections from people they had not met in real life and that was limited to seeking out people with a common interest in a specific type of music - the now-classic use of the interconnections possible online to find common travellers [which the subject referred to as 仲間 (nakama - friend, partner, companion)] with a shared minority interest.

13 Electronic Frontier Foundation (2003). EFF "Legal Cases - Jake Baker, the U. of Michigan, \& the FBI" Archive. w2.eff.org/legal/cases/Baker_UMich_case.

14 CBC (2009). Depressed woman loses benefits over Facebook photos. www.cbc.ca/news/canada/montreal/story/2009/11/19/quebec-facebook-sick-leave-benefits.html.

15 Halliday, J. (2011). Tory MP Louise Mensch backs social network blackouts during civil unrest. The Guardian, 12th August. www.guardian.co.uk/uk/2011/aug/12/louise-mensch-social-network-blackouts. 
...members are my university friends or friends from high school only. I don't like to have a communication with unspecified people through the websites.

Japanese Student, Male, 21 (translated)

I want to track down my old school friends, from elementary school to high school, on the Mixi web site; I would like to find friends who have real relationships with me through using Mixi. I don't hold my breath to make a new personal relationship with those who share the same interest with me online.

Japanese Student, Male, 21 (translated)

I've got about 600 friends. They have to be someone I definitely know. I put up all the information about hobbies, music, what I'm doing in my degree, all my religious and political views, things like that.

UK Student, Female, Age not recorded

I wanted to find fellows [仲間 (nakama)] with whom I could enjoy talking over and exchanging information of heavy metal music and musicians. I didn't have any nakama to do such things before using Mixi; joining open communities of heavy metal music in Mixi provided me with the opportunities to get acquainted with those who had the similar taste of music and now enjoy good relationships with them not only in the cyberspace but in the real space.

Japanese Student, Male, 19 (translated)

Both UK and Japanese interviewees felt pressure from their peer groups to be involved in the SNS, with both reporting that they used the sites to keep in touch with their pre-university social circle, as well as those they had met since starting university. Even those attending university in Tokyo who are from Tokyo, use the site to keep in touch with friends attending a different Tokyo-based institution, with whom they felt they might otherwise have lost touch.

\section{Friends Don't Embarrass Friends Online}

Another common thread between the UK and Japanese interviewees was their attitudes to revelation of others' information on their SNS sites. Almost all of both groups felt that unrestricted revelation was not a proper way to act on such sites. It was felt by members of both groups that information with potentially negative consequences should either not be posted, or at least that the subject should be consulted before posting. Both Japanese and UK subjects were aware of the potential negative consequences of posting embarrassing photos online, even if the intent and initial audience is a tight circle of known individuals.

I have been concerned that one of my university friends uploaded two photographs which show a girl (ed: not interviewee's partner) and me together. After that, I worried that her boyfriend may complain to me. In another case, while I don't disclose my department/course or name of my university, some user disclosed it without my agreement. 
Some of the Japanese interviewees regarded the subject of revelations as equally to blame as the person making the revelation, for any negative consequences arising. The UK interviewees regarded it as solely the responsibility of the revealer. This may well reflect broader Japanese attitudes to group assumption of blame and consequences, drilled into youngsters from their first days at kindergarten or school according to Hendry. ${ }^{16}$ It also mirrors other elements of Japanese culture with regard to negative consequences of social interactions, for example the greater reluctance of Japanese junior high school students to report instances of bullying as shown by Kanetsuna et al. ${ }^{17}$ Informal class discussions with a group of Japanese university students and two of the authors about online bullying also revealed the attitude that the victim is somehow jointly to blame with the victimiser.

When Mixi stalking happens, this is a victims fault. Mixi users have to carefully determine what kinds of information can and cannot be published on Mixi. Information provision which evokes Mixi stalking can perfectly be deterred if users have enough knowledge about the Internet.

Japanese Student, Male, 19 (translated).

\section{Conclusions}

The sample size for these interviews is very small. Hence conclusions are only drawn about these particular interviewees. There are two intended tracks for following up on this work: developing and deploying a questionnaire about SNS usage targetted at confirming whether the interviewees were representative of their peer groups in their attitudes; comparison of the results of these interviews with the larger interview sample of Canadian residents (mostly Canadian citizens) undertaken by Trottier, on whose questions this work was based. Funding is being sought to perform these and related pieces of research.

Fear of isolation/peer pressure is the key to why the interviewees use SNS. Even where there is disquiet about the dangers of SNS usage, or the policies of a particular platform operator, almost all interviewees felt that they had to be online or be excluded from their social group. The one interviewee who had chosen not to be on SNS felt that they had to work harder to engage with the social group because of their lack of inclusion in the network, with other electronic communications tools such as email and SMS being their preferred modes of online contact.

The Japanese interviewees reported somewhat greater usage than the UK interviewees. This may be simply a reflection of the small sample size, but might also be reflective of the greater availability of featurephonebased SNS access in Japan at the time of the interviews (2009-10). The spread of smartphones in the UK may have reduced this difference by the time of writing (late 2011).

Most of the interviewees had some awareness of privacy boundaries, but it varies greatly and may be subject to large shifts from small causes. This gives hope for digital identity awareness training of the type promoted by the Williams et al. ${ }^{18}$ in the This is Me project (thisisme.rdg.ac.uk). All of the interviewees recognised there were dangers to their privacy in using SNS, with this awareness sometimes triggered by a specific instance of their own use and sometimes by things that happened to others (reported by word of mouth in the case of their friends or through the media for other people).

16 Hendry, J. (2003). Understanding Japanese Society. Routledge, Oxford.

17 Kanetsuna, T., Smith, P. K., and Morita, Y. (2006). Coping With Bullying at School: Children's Recommended Strategies and Attitudes to School-Based Interventions in England and Japan. Aggressive Behavior, 32(6):570-580.

18 Williams, S., Fleming, S., Lundqvist, K., and Parslow, P. (2011). Understanding Your Digital Identity. Learning Exchange, 1(1). learningexchange.westminster.ac.uk/index.php/lej/article/viewFile/17/14. 
Recently, I have been very careful in writing a Facebook journal so that the writing will never cause any problem assuming that anyone can read the journal. I recognised this necessary (sic) through reading news reports about Facebook stalking by organisations.

UK Student, Male, 21.

I changed my profile picture, and I had about 15 people making a mess of my Facebook page all over the place, putting things on the wall. I looked at my wall and looked at my profile on there, and basically felt that it wasn't representative of what I wanted people to see, it was a representation of what other people wanted. And thinking about placements and trying to get a job this summer, I was thinking I wouldn't want people who might be working with me, or might be looking to employ me in the future, to see all this stuff. I wasn't really bothered about it until then. And then a switch flipped, and I thought I don't want people seeing this, or pictures tagged to me, and this, that and the other.

I spent an hour buried in the Facebook privacy things and the application settings, basically turning everything off....no one [else] can now do anything on Facebook which changes my profile.

UK student, Male, 20.

I used to put quite personal stuff on there, but recently I've not been doing that so much. I just began to realise how stuff I put online is going to stay there, and people can access it quite easily. You've realIy got to think about it whereas before I used to put quite random stuff on there. I began to use Live Journal rather than Facebook for publishing stuff. I put a few status updates, that kind of thing, but not very much.

UK Student, Male, Age not recorded.

My parents are online, so I monitor what I put up on Facebook. I mean you can't refuse a request from your parents to be your 'friends', but I remove things like pictures of me smoking, or lewd comments on my wall that I might not want them to see!

UK Student, Female, Age not recorded

I experienced the event where my father asked me to let him be my Facebook friend. If he hadn't sent me the message, I would not have realised he had access to my Facebook pages. Japanese Student, Male, 21 (translated)

I never upload my photograph, real name and something by which someone can identify me. It is OK for me to reveal the name of my university on Mixi. 


\section{References}

Aspray, W. and Doty, P., editors (2011). Privacy in America: Interdisciplinary Perspectives. Scarecrow Press, Lanham, MD.

CBC (2009). Depressed woman loses benefits over Facebook photos. www.cbc.ca/news/canada/montreal/story/2009/11/19/quebec-facebook-sick-leave-benefits.html.

Electronic Freontier Foundation (2003). EFF "Legal Cases - Jake Baker, the U. of Michigan, \& the FBI" Archive. w2.eff.org/legal/cases/Baker UMich casel. Last Update.

Halliday, J. (2011). Tory MP Louise Mensch backs social network blackouts during civil unrest. The Guardian. 12th August. www.guardian.co.uk/uk/2011/aug/12/louise-mensch-social-network-blackouts.

Hendry, J. (2003). Understanding Japanese Society. Routledge, Oxford.

Kanetsuna, T., Smith, P. K., and Morita, Y. (2006). Coping With Bullying at School: Childrens Recommended Strategies and Attitudes to School-Based Interventions in England and Japan. Aggressive Behavior, 32(6):570-580.

Livingstone, S. (2008). Taking risky opportunities in youthful content creation: teenagers' use of social networking sites for intimacy, privacy and self-expression. New Media and Society, 10(3):393-411. eprints.Ise.ac.uk/27072/1/Taking risky opportunities in youthful content creation (LSERO).pdf.

Marwick, A. E., Murgia Diaz, D., and Palfrey, J. (2010). Youth, Privacy and Reputation (Literature Review). Technical Report 5, Berkman Centre. ssrn.com/abstract=1588163.

Marwick, M. and boyd, d. (2011). Tweeting teens can handle public life. The Guardian. www.guardian.co.uk/commentisfree/2011/feb/15/tweeting-teens-twitter-public-privacy.

Marx, G. T. (2011). Turtles, Firewalls, Scarlet Letters and Vacuum Cleaners: Rules about Personal Information. In Aspray and Doty (2011). Early draft available at web. mit.edu/gtmarx/www/turtlesandfirewalls. html.

Matsuzawa, Y. (2011). Kosei Gakuin: the fact that three baseball players drank was detected online and they were suspended from school. Mainichi Shimbun. 22nd August. mainichi.jp/select/today/archive/news/2011/08/22/20110823k0000m040055000c.html. In Japanese.

Microsoft (2010). Data Privacy: Perceptions Study. download.microsoft.com/download/E/0/9/E094917B049C-4B00-AE65-E97F55585C08/DPD \%200nline\%20Reputation\%20Research.pptx. A survey whose results were widely reported in the press but for which no better presentation of the results is extant.

Out-Law.com (2010). German law bans facebook research for hiring decisions. www.out-law.com/page$\underline{11336 .}$

Solove, D. J. (2007). The Future of Reputation. Yale University Press, New Haven, CT.

Wall Street Journal (2011). Booze of Summer: Scandal Hits Koshien Baseball . blogs.wsj.com/japanrealtime/2011/08/25/booze-of-summer-scandal-hits-koshien-baseball/. JapanRealTime Blog.

Williams, S., Fleming, S., Lundqvist, K., and Parslow, P. (2011). Understanding Your Digital Identity. Learning Exchange, 1(1). learningexchange.westminster.ac.uk/index.php/lej/article/viewFile/17/14.

Wobbema, T. (2009). U student suspended after threatening remarks on Facebook. The Minnesota Daily. www.mndaily.com/2009/12/16/u-student-suspended-after-threatening-remarks-facebook. 